\title{
Interfaces
}

"Never shake thy gory locks at me" (Macbeth, III.iv. 50-51): Objecting to Gestures in Macbeth

\section{Claire Guéron}

\section{Q OpenEdition \\ 1 Journals}

\section{Electronic version}

URL: http://journals.openedition.org/interfaces/602

DOI: 10.4000/interfaces. 602

ISSN: 2647-6754

\section{Publisher:}

Université de Bourgogne, Université de Paris, College of the Holy Cross

\section{Printed version}

Date of publication: 21 December 2018

Number of pages: $67-84$

ISSN: 1164-6225

\section{Electronic reference}

Claire Guéron, "'Never shake thy gory locks at me" (Macbeth, III.iv.50-51): Objecting to Gestures in Macbeth", Interfaces [Online], 40 | 2018, Online since 21 December 2018, connection on 07 January 2021. URL: http://journals.openedition.org/interfaces/602 ; DOI: https://doi.org/10.4000/interfaces. 602

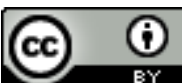

Les contenus de la revue Interfaces sont mis à disposition selon les termes de la Licence Creative Commons Attribution 4.0 International. 


\title{
"NEVER SHAKE THY GORY LOCKS AT ME" (MACBETH, III.IV.50-51): OBJECTING TO GESTURES IN MACBETH
}

\author{
Claire Guéron \\ Université de Bourgogne-Franche-Comté
}

\begin{abstract}
Shakespeare's Macbeth displays a pattern of characters objecting to gestures, be it others' or their own. This includes Macbeth refusing to shake hands with his opponent before the battle, his words to Banquo's ghost quoted in the title above, Banquo's own puzzlement at the weird sisters' placing a finger over their lips, the doctor's suspicions at Lady Macbeth's rubbing her hands and sleepwalking, as well as Malcom's request that Macduff not pull his hat over his eyes. In many of these cases, gesture is pitted against speech, which seems to undermine the classically-derived ideal of "suit[ing] the word to the action, the action to the word" (Hamlet, 3.2.16-18). This essay will suggest that in Macbeth, speech/gesture dissociation meta-dramatically channels the play's representation of heroic decline into an exploration of non-mimetic ways of generating suspense, empathy, and catharsis, in keeping with the turn towards pantomime and pageantry that marked early seventeenth-century drama.
\end{abstract}

Résumé: Dans le Macbeth de Shakespeare, on relève une accumulation de répliques par lesquelles un personnage s'oppose à une gestuelle, qu'il s'agisse de la sienne ou de celle d'un autre. On pense au moment où Macbeth refuse de serrer à main à son adversaire avant un combat singulier, à la réplique citée en titre cidessus, correspondant au moment où Macbeth demande au fantôme de Banquo, sa victime, de ne pas secouer la tête, à l'étonnement manifesté par Banquo lui-même lorsque les sorcières portent un doigt à leurs lèvres, aux soupçons du médecin lorsque Lady Macbeth se frotte les mains dans un accès de somnambulisme, et à l'injonction de Malcom qui demande à Macduff de ne pas rabattre la visière de son couvre-chef sur ses yeux. Dans ces exemples, le geste est souvent opposé à la parole, ce qui semble aller à l'encontre de l'idéal d'éloquence néo-classique qui, pour reprendre la formule de Hamlet, consiste à: " [r]égle[r] le geste sur le mot, et le mot sur le geste " (Hamlet, 3.2.17-18) ${ }^{1}$. On se proposera ici de montrer que dans Macbeth, la dissociation du geste et de la parole permet, par méta-théâtralité, de faire de la représentation du déclin de l'héroïsme le vecteur d'une réflexion sur certaines stratégies non mimétiques de création du suspense, de l'empathie et de la catharsis, dans le cadre d'un théâtre du début du dix-septième siècle qui fait la part belle au spectaculaire et à la pantomime.

Traduction de Jean-Michel Déprats, dans Shakespeare, Tragédies I, La Pléiade, Gallimard, dir. J-M. Déprats et G. Venet, 2002. 
The words above, spoken by Macbeth to the ghost of Banquo, one of his victims, are part of a pattern in Shakespeare's Scottish play, whereby characters object to gestures performed by others, in lines anaphorically linked together by the adverb "never". At the beginning of the play, when the wounded captain is describing Macbeth's defeat of the rebel Macdonald, he says that Macbeth "ne'er shook hands" with his opponent until he had "unseamed him from the nave to the chops" (I.ii.22). Near the end, when Ross has delivered to Macduff the ill news of the slaughter of his family, Malcolm objects to the bereaved husband and father's response: "ne'er pull your hat over your brows; / Give sorrow words" (IV.i.209-210).

Though such repetitions may seem more salient to a present-day audience than to an early modern one due to the now archaic use of "never" for "do not", it is nevertheless significant that a pattern of rejection of gestures appears in a play that stages a crisis of the heroic, a play written and performed at a time when signifying gestures, especially those of a ritual kind, were coming under suspicion. Objection to gestures is thus readily contextualized in the light of early seventeenth-century culture, characterized in England by the last gasps of the trial by combat, anti-Catholic sentiment in the wake of the 1605 Gunpowder Plot, and increasingly textual modes of knowledge. To some extent, Macbeth may reflect these developments. Yet this was also a time when the role of gesture in dramatic performance was being emphasized by such writers as Thomas Heywood, with the backing of classical rhetoricians such as Cicero and Quintilian. An anti-gesture stance is at any rate essentially paradoxical in a dramatic work, which relies on the constant interplay of word and gesture to produce meaning. The pattern of objection identified above, which pits the spoken word against the performed gesture, suggests that it is the nature of this interplay, rather than gesture per se, that is at stake. In the following essay, I will argue that in Macbeth Shakespeare appropriates the historical decline of the heroic gesture as a way to meta-dramatically probe the link between speech and gesture in theatrical performance. I will first suggest that Macbeth establishes the heroic gesture as a signifying one, in which action, meaning and word are tightly bound up. However, this link is tested in the course of the play, where words and gestures tend to develop into independent and sometimes contradictory signifying systems. Such semiotic dissociation, I will argue, allows Shakespeare to distance himself from classical and contemporary rhetorical models of dramatic action, and demonstrate the dramatic effectiveness of exploiting the gap between word and gesture. 


\section{The meaningful gesture: from heroic to rhetorical efficacy}

In its most dramatic moments, Macbeth evokes the heroic ideal of the gesture that vindicates the gesturer and proves the righteousness of his cause. In the ethos of the heroic tradition, which found its expression in the medieval trial by combat and its literary counterparts (epic, chanson de geste and chivalric romance), the heroic gesture combined action and signification. The hand that felled or slew an opponent was guided by God, and victory meant vindication. This is what the ideal young Seyward evokes when he challenges Macbeth to single combat, with the words "Thou liest abhorrèd tyrant, with my sword/ I'll prove the lie thou speak'st" (V.vii.10-11). The same principle is invoked earlier in the play by Macbeth himself in his challenge to the ghost of Banquo. After (mendaciously) denying guilt in Banquo's death, Macbeth asks the ghost to "dare [him] to the desert with [his] sword" (III.iv.105) so that he may prove his innocence in an ordeal by combat. The dynamics of trial by combat are eventually carried out when Macduff kills Macbeth in single combat, thus proclaiming the tyrant's illegitimacy. Malcolm's closing words, with a promise to perform what needs doing "in measure, time, and place" (V.vii.103), assert the principle of kingly rule as the proper use of purposeful gestures. This vision of kingship also appears in Malcolm's earlier reference to the historical King Edward the Confessor, known for healing scrofula with his touch, an apt symbol of hope for an ailing Scotland (IV.iii.146159). The "King's Touch" is another of those perfect performative actions, in which doing and saying are simultaneous. When laying his hands on an afflicted subject, the king is both effecting a cure and proclaiming his legitimacy. If the king's hands can heal, then he is the rightful ruler.

This close association of gesture, action and meaning is neatly encapsulated in the term "geste", as it appeared in the chanson de geste genre. The chanson de geste was a medieval heroic poem, its name reflecting the medieval acceptation of "geste" as "great feat of heroic action" (OED, entry 1). The term could in fact refer both to the action itself, and to the story of that action, implying a perfect fit between the two. By 1509 (OED, entry 2), "geste" also meant "gesture", suggesting that some overlap between the three meanings of "heroic action", "heroic tale" and "gesture" was perceptible in the early modern period. In Macbeth, the passage that comes closest to the poetics of the chanson de geste may be the wounded captain's early description of Macbeth's heroic fight against the traitor Macdonald:

For brave Macbeth - well he deserves that name -

Disdaining Fortune, with his brandished steel

Which smoked with bloody execution,

Like Valour's minion carved out his passage

Till he faced the slave -

Which ne'er shook hands nor bade farewell to him, 
Till he unseamed him from the nave to th'chops,

And fixed his head upon our battlements. (I.ii.16-23)

This tale of violent action, like the chanson de geste, illustrates the close connection between gesture, action and meaning that underpins the medieval ethos of heroic narratives. In addition to this, by dint of being integrated in a dramatic performance, the speech brings in the additional layer of the captain's gestures as he tells the story. In this respect, the passage probably owes as much to the classical Senecan tradition as to the medieval heroic one.

Elizabethan tragedy grew out of the Roman tragedies of Seneca, which involved little stage action, but long, highly ornamental speeches by messengers reporting off-stage events presumably accompanied by suitable gestures. Macbeth thus begins in a very Senecan manner, though the "ne'er shook hands" negation on line 21 may hint at a later problematizing of heroic gesture. As Nicholas Brooke points out in his introduction to the Oxford edition, the Captain's speech is that of a classical messenger (Macbeth 58). The Captain is indeed a choric character, but also a man of action, and the words - especially "brandished" - lend themselves readily to illustrative gestures. Elsewhere in the play, appropriateness of gesture to speech is suggested by the ample use of deictics - demonstrative words such as "this", "here" or "there" - which verbally gesture towards their referent, and may imply a physical gesture as well. For example, Macbeth's words when seeing (or imagining) the ghost of Banquo ("Prithee see there - behold, look, lo"; III.iv.68) call for accompanying gestures. What is particularly significant about the Captain's speech, though, is that his tale allows for the "natural gestures" of Macbeth to be processed as "dramatic action".

In his article entitled "Meta-theatrical rhetoric in Shakespeare", John H. Astington points to a distinction in Shakespeare's use of the words "action" and (less frequently) "gesture". "Action", he argues, "is a term referring particularly to mimetic activity" while " gesture' seems reserved for the actions of fictional characters" (242). The captain's performed actions, as he tells the story, thus duplicate Macbeth's gestures, in a way that transfers the immediacy of heroic gesture to the realm of rhetorical and theatrical representation.

The dramatic use of the term "action" as Astington also reminds us (p.243), derived from Ciceronian rhetoric. In classical oratory, "action" 2 - or actio - was the sixth part of rhetoric, and referred to the gestures, facial expressions and intonation accompanying a speech's delivery. Classical authors such as Cicero and Quintilian stressed that without action, a speech was dead letter, and unable to achieve the goal of rhetoric, which was, in its purest form, to move the listener to virtuous 
emotions and behaviour. For example, Quintilian affirms that "all emotional appeals will inevitably fall flat, unless they are given the fire that voice, look and the whole carriage of the body can give them" (Quintilian 245). ${ }^{3}$

In the late sixteenth and early seventeenth centuries, rhetorical treatises of the classical age were eagerly taken up by playwrights seeking to co-opt the respectability of ancient rhetoric for an often maligned profession. For example, based on the principle that "in the substance of external action for most part oratours and stage players agree" (Wright 179), playwright Thomas Heywood, in his Defense of Drama (1608), justified playacting by stating that it shared with rhetoric a concern with word/gesture decorum:

[Rhetoric] instructs [the scholar] to fit his phrases to his action, and his action to his phrase, and his pronunciation to them both. (Heywood 490)

This classical precept may have reached Heywood by way of Shakespeare's Hamlet, who in his advice to the players instructed them to:

Suit the action to the word, the word to the action, with this special observance, that you o'erstep not the modesty of nature. (Hamlet, III.ii.16-18)

In both statements, the mutual containment of word and action is suggested by a chiastic structure, connoting balance and restraint. Like the orator's gesture, then, the actor's is conducive to truth-telling and to inciting temperance. In addition, harmony between speech and gesture produces a realistic effect, suitable to moral exempla. For Heywood,

A description is only a shadow, received by the ear but not perceived by the eye; so lively portraiture is merely a form seen by the eye, but can neither show action, passion, motion, or any other gesture to move the spirits of the beholder to admiration. But to see a soldier walk, speak, act like a soldier [...]. These were sights to make an Alexander! (Heywood 487)

Quintilian goes on to adduce the popularity of the stage over the library as proof that delivery matters more than content. Cicero, however, tends to invoke the stage as a counter-example, stressing the difference between the hammed-up performances of actors and the naturally flowing gesture of the orator: "on all these emotions a proper gesture ought to attend; not the gesture of the stage, expressive of mere words, but one showing the whole force and meaning of a passage" (Cicero, Book 3, LIX). 
The rhetorical effectiveness of word/gesture agreement thus easily transfers from the Roman forum to the early modern stage. In the play, the rhetorical persuasiveness of gesture in support of words is on display when the weird sisters show Macbeth a pageant of spirits representing Banquo's descendants. Macbeth is convinced of the truthfulness of the sisters' prediction that Banquo will father a line of kings when he sees his spirit pointing to the images of his royal offspring:

Horrible sight - now I see "tis true,

For the blood-baltered Banquo smiles upon me,

And points at them for his. (IV.i.137-139)

Pointing, as Farah Karim-Cooper reminds us, was a frequently performed gesture on the early modern stage, often denoting self-affirmation and authority (Karim-Cooper 71), ${ }^{4}$ as in this contemporary illustration of Titus Andronicus by Henry Peacham, showing Tamora pleading for her sons' lives with Aaron the Moor standing to the right (Figure 1).

In Macbeth, the effective gesture often takes on a meta-dramatic dimension, as when martial victory is equated with gestures of display. In particular, the victory of the Anglo-Scottish alliance against Macbeth is heralded and facilitated by a series of demonstrative gestures, including the fighters' removal of their leafy camouflage, Macduff's threat to display Macbeth in chains with a sign over his head (V.vii.57), and his final display of the tyrant's severed head while speaking the explanatory words “behold where stands/ Th'usurper's cursed head" (V.vii, 84-5). Moreover, the fighter's "leafy screens" (V.vi.1), resemble nothing so much as an actor's mask, and, in the example of Banquo pointing, the object on display happens to be a piece of pageantry. Similarly, the King of England's magic touch is described as part of an elaborate spectacle, including the ritual placing of a medal around the sufferer's neck and a spoken benediction (IV.iii.153-4). In this way, the effectiveness of a character's heroic gesture meta-dramatically reflects the classically inspired ideal of the player's perfect coordination of speech and action.

The corollary of this analogy is that the breakdown of the heroic staged by the play, which involves a semiotic emptying out of gesture, tests the bond between dramatic speech and staged action.

Banquo's gesture is in fact doubly productive. Not only is it rhetorically convincing, but it is generative, as it effectively establishes his fatherhood, or - in the loaded terminology of the time - authorship, of a line of kings. 


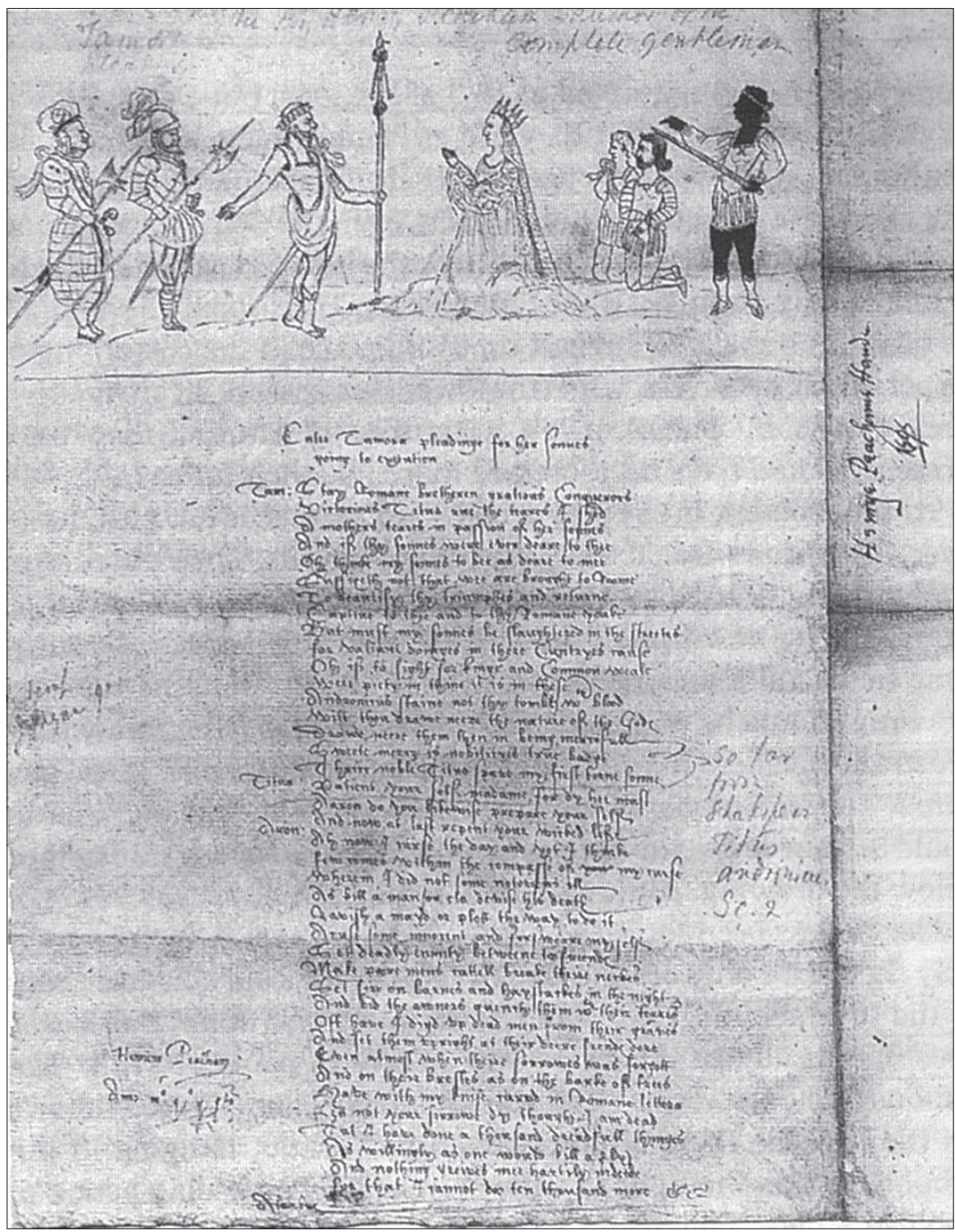

Figure 1: Henry Peacham. Pen and ink sketch illustrating a performance of Titus Andronicus (1595) from the Longleat Manuscript at the library of the Marquess of Bath, Longleat House, Wiltshire. Public domain (Wikimedia Commons). 


\section{Testing the bond between speech and gesture}

In Macbeth, the breakdown of the heroic ethos is staged as a failure of the heroic gesture to signify truly. In particular, the vindicating power of the challenge to single combat fails repeatedly, first when Macbeth challenges a ghost to a duel in order to prove what is clearly a lie, to wit, his innocence, then when young Seyward is felled by Macbeth's sword in spite of the truthfulness of his accusation. In fact, this semiotic emptying out of the gesture is at work almost from the beginning, with the Senecan episode of the bleeding Captain's tale constituting the play's last example of a perfect fit between gesture, action and word. Cracks begin to appear soon afterwards, when King Duncan congratulates Macbeth on his victory against the traitor.

Duncan is characterized as a genial man, who is given to expressing his gratitude with gestures, both performed and described. After Macbeth and Banquo have defeated the rebels, Duncan speaks of rewarding them in very kinetic terms, as he successively evokes a bird in flight, a gardener planting trees, and finally himself embracing the victors:

Thou art so far before

That swiftest wing of recompense is slow

To overtake thee. [...]

I have begun to plant thee, and will labour

To make thee full of growing. - Noble Banquo

Thou hast no less deserved, nor must be known

No less to have done so - let me enfold thee,

And hold thee to my heart. (I.iv.17-33)

In addition to the flying, planting and holding motions it alludes to, the speech seems to code for an accompanying embrace to be performed. However, the kinetic potency of the passage is deflated in the next lines, when Duncan voids the enticing promise of a fruitful gesture by verbally bestowing the succession on his son, much to Macbeth's chagrin. Later in the play, an enraged Macbeth similarly speaks of unsatisfactory promises as unproductive gestures when he complains about the weird sisters promising him the crown of Scotland, but only for his lifetime: "upon my head they placed a fruitless crown/ and put a barren sceptre in my gripe" (III3.i.60-61). In Macbeth, such gestures are unproductive in more ways than one, often partaking of the play's equation of heroic loss with infertility.

The play's staging of a crisis of the heroic gesture reflects several contemporary developments in the fields of politics, religion, and theatrical culture. In spite of their Golden Age aura, the Tudor 
and early Stuart years were marked by a sense of decline from a heroic past, as reflected in a fondness for medieval-style jousting and antiquarian pursuits. This sense of decline included a loss of faith in gestural efficacy, as trial by combat became a rare curiosity ${ }^{5}$ and power was increasingly wielded by men of law and other sifters of written evidence. Another momentous sixteenth-century development was the Reformation, with its rejection of "popish" ritual gestures in favour of the written word and the inner motions of faith. The seventeenth-century rise of the Puritan faction in Parliament and the anti-Catholic sentiment stirred by the failed Gunpowder Plot of 1605 meant that suspicion of ritual gesture must have been particularly rife at the time of Macbeth's production in 1606.

Suspicion of gesture spilled over to the realm of the theater, as Puritan anti-theatrical sentiment was often expressed as a condemnation of theatrical gestures, deemed lascivious and indecent. For example, playwright-turned-Puritan Stephen Gosson accused actors of "using effeminate gesture, to ravish the sense" (qtd. in Karim-Cooper 111) while Philip Stubbes denounced "the shameless gestures of players [which] serve to nothing so much as to move the flesh to lust and uncleanness" (qtd. in Cooper 112). Though defenders of the theater countered these attacks with the references to classical rhetoric discussed above, dramatic authors themselves meta-dramatically expressed uneasiness about unseemly or parasitical stage gestures, as when Hamlet instructs a troupe of visiting players not to "saw the air with [their] hand[s]" (III.ii.4-5), or when Thomas Nashe's Will Summers tells the players of Summer's Last Will and Testament not to fidget when they don't know what to do with their hands:

And this I bar, over and besides: that none of you stroke your beards to make action, play with your codpiece points, or stand fumbling with your buttons when you know not how to bestow your fingers. (Nashe 149) ${ }^{6}$

Such recommendations, beyond the common-sense advice they clearly constitute, may reflect uneasiness about an early seventeenth-century aesthetic trend, whereby various embedded spectacles interrupted and perhaps sometimes upstaged dialogue in the construction of dramatic meaning. Uneasiness of this kind may be perceptible in Thomas Dekker's A Knights Conjuring Done in Earnest, where a man gesturing wildly is compared to a player who has forgotten his lines: "with pityfull

The last trial by combat in Britain is believed to have taken place in Scotland in 1597 (Megarry 66).

This type of "advice to the players" seems to have become something of a set piece in the early seventeenth century. Richard Brome's The Antipodes provides a later example, with Lord Letoy's words to the household members about to embark on a performance designed to deceive their master into thinking he has travelled to the Antipodes: "And you, sir, you had got a trick of late/ Of holding out your bum in a set speech;/ Your fingers fibulating on your breast/ As if your buttons, or your Band-strings were/ Helpes to your memory. Let me see you in't/ No more, I charge you" (II.ii.21-26). 
action, like a player (when he is out of his part) made singes to have a letter delivered in a dumb show" (chapter VII 33). The ridicule showered on the wildly-gesturing man carries over to the dumb show, here characterized as a defective form of dramatic expression, lacking the grace and clarity of speech. Similarly, Hamlet's "advice to the players" contains a critique of "inexplicable dumb-shows" (III. ii.12), notwithstanding his own conniving at the performance of a dumb show in the very same scene. These offhand dismissals, in fact, fly in the face of the form's growing relevance to early seventeenth century drama. ${ }^{7}$ The dislocation of the word/gesture continuum implied by the dumb show was part of a noticeable turn towards spectacle and pageantry in early seventeenth-century drama, in a move away from the balanced model of classical rhetoric.

As John Wesley has recently argued, the trope of the actor/orator homology was fraying at the edges by the early seventeenth century, as "theories of acting began to evolve independently of rhetoric" (Wesley 73). Even those playwrights / critics who took up the oratorial principle of word/ gesture suitability did not necessarily practice what they preached, for even as that ideal was being invoked, the early seventeenth century stage was reviving and absorbing forms of entertainment premised on some degree of speech/gesture dissociation, testifying to a renewed interest in the various possible configurations of these two expressive systems. Along with the dumb show, such forms of entertainment included the court masque, with its alternation of dance and dialogue, the royal pageant, with its alternation of speeches and processions, and the puppet show, with its ventriloquizing.

Macbeth integrates several of these disjunctive forms. For example, the scenes with the witches resemble the antimasque in Ben Jonson's Masque of Queenes, which the author describes as "a spectacle of strangeness, producing a multiplicity of Gesture" (345). ${ }^{8}$ Macbeth's second encounter with the witches also integrates elements of the dumb show, the royal pageant and the puppet show. In particular, the three diminutive apparitions conjured up by the witches - an armed head, a bloody child and a child crowned - evoke a puppet show, especially as the witches stand by and comment,

Though the dumb show existed from the early days of Elizabethan drama, and probably derived from medieval pageantry, the years from 1590 on saw a move towards a greater integration of dumb show and dramatic action. On this see Mukherji (98), Lopez (295) and Mehl (65).

8 Jonson was the inventor of the antimasque, a grotesque episode involving demonic creatures such as witches or goblins, representing the forces of darkness and chaos, which functioned as a foil to the masque proper. The gesticulating and noise characterizing the anti-masque stood in contrast to the harmonious music and ornate speech that followed. The tension between gesture and speech is made quite explicit in the rest of Jonson's stage directions for the antimasque: "These eleven witches beginning to dance, which is an usual Ceremony at their Convents, or Meetings, $[\ldots]$ on the sudden, one of them missed their Chief, and interrupted the rest with this Speech" (345). 
like the "interpreter" in such forms of popular entertainment. ${ }^{9}$ An added point of contact between Macbeth and the puppet show is the fact that a favourite subject of early seventeenth-century puppet shows was the Gunpowder Plot, which, as Gary Wills has shown, informs much of Macbeth (Wills 8; Barasch 171). These generic disjunctions of speech and gesture are harnessed in the play's instances of objecting to gesture, which often involve a word/gesture opposition. The most emblematic instance of this opposition may reside in the weird sisters placing a finger on their lips, a universal gesture enjoining silence or expressing an inability to speak. This occurs in the scene of Macbeth and Banquo's first encounter with the witches:

\author{
BANQUO \\ Live you, or are you aught \\ That a man may question? You seem to understand me, - \\ By each at once her choppy finger laying \\ Upon her skinny lips. You should be women \\ And yet your beards forbid me to interpret \\ That you are so. \\ MACBETH (To the witches): \\ Speak if you can: what are you? \\ FIRST WITCH \\ All hail Macbeth, hail to thee thane of Glamis \\ SECOND WITCH \\ All hail Macbeth, hail to thee thane of Cawdor \\ THIRD WITCH \\ All hail Macbeth, that shalt be King hereafter \\ BANQUO \\ Good sir, why do you start, and seem to fear \\ Things that do sound do fair? (I.iii.42-52)
}

The passage is built on a systematic tension between gestures and speech. The witches first attempt to inhibit speech with a gesture, which does not prevent Banquo and Macbeth from pressing forward with their questions. When the witches do speak, the first word of their anaphoric lines, "hail", denotes a gesture. Macbeth then reacts with an involuntary movement, prompting Banquo to speak again. The emphasis on gesture and on items suggestive of theatrical cross-dressing (the beards) gives the passage a meta-dramatic dimension. The witches are an example of how such eerie creatures as

The interpreter, as Frances K. Barasch explains, "stood outside the puppet booth, announced the play, introduced its characters, narrated events, and explained puppet actions” (Barasch 168). 
ghosts, spirits and sleepwalkers, with their inherently unnatural articulation of speech and gesture, can be enlisted for a demonstration of the dramatic effectiveness of speech/action disconnection. It is certainly no accident that the ghost of Banquo, unlike that of Hamlet's father, does not speak. Given that such uncanny character types are theatrical vehicles of fear, curiosity, pity and awe, they offer the dramatist an opportunity to explore how various combinations of speech and gesture may work towards those effects, and towards achieving suspense, empathy and catharsis.

\section{Suspense, Empathy and Catharsis}

The word "suspense" did not exist in Shakespeare's day, but Elizabethans and Jacobeans were certainly familiar with states of anxious anticipation. Taking Macbeth's objection to the ghost of Banquo shaking his head, we are given a picture not only of guilt and fear, but also of spectatorial frustration and desire. "if thou cans't nod, speak, too!" Macbeth urges (III.iv.70). Such spectatorial frustration is both dramatized and implemented in Lady Macbeth's sleepwalking scene.

The preamble to the famous sleep-walking scene, in which a guilt-wracked Lady Macbeth rubs her hands in an attempt to remove imagined blood-stains, involves an immediate dissociation of speech and gesture, as the Gentlewoman describes her mistress's gestures to the Doctor, but pointedly refuses to report what she has said:

GENTLEWOMAN: I have seen her rise from her bed, throw her nightgown upon her, unlock her closet, take forth paper, fold it, write upon't, read it, afterwards seal it, and again return to bed; yet all this while in a most fast sleep.

DOCTOR: A great perturbation of nature, to receive at once the benefit of sleep, and do the effects of watching. In this slumbery agitation, besides her walking and other actual performances, what, at any time, have you heard her say?

GENTLEWOMAN: That, sir, which I will not report after her.

DOCTOR: You may to me, and 'tis most meet you should.

GENTLEWOMAN: Neither to you, nor to anyone, having no witness to confirm my speech. (V.i.3-17)

The Gentlewoman's insistence that she cannot report Lady Macbeth's words without a witness sounds like a nod to the budding "hearsay" laws being hammered-out in England's courts of law at the 
time. ${ }^{10}$ With her willingness to report gestures, but not speech, the gentlewoman establishes words, as opposed to gestures, as evidence, in a way that reflects the turn towards witness depositions and trial by jury in contemporary courtrooms. ${ }^{11}$ This nod to the extra-dramatic realm of legal enquiry gives weight to the speech-gesture divide, preparing for its use as a dramatic device in the next part of the scene, when the guilt-stricken murderess makes her entrance, rubbing her hands:

\section{DOCTOR}

What is it she does now? Look how she rubs her hands.

GENTLEWOMAN

It is an accustomed action with her, to seem thus washing her hands: I have known her continue in this a quarter of an hour.

LADY MACBETH

Yet here's a spot.

DOCTOR

Hark! She speaks [...]. (V.i.25-31)

How much time should elapse between the Gentlewoman's speech and Lady Macbeth's words is up to the director and the actor playing Lady Macbeth, but the reference to a quarter of an hour indicates that an interval is called for, during which Lady Macbeth will rub her hands in silence. We can imagine a naive member of the audience wondering if they are really going to have to sit - or stand - through fifteen minutes of Lady Macbeth rubbing her hands, but most will feel only tantalizing awareness that words are soon to follow. How long the hand-rubbing goes on will most likely depend on the degree of impatience displayed by the audience. What Shakespeare is meta-dramatically demonstrating here is a tactic frequently employed at the beginning of a performance, when some wordless action is performed as the audience settles down. A 2000 New Globe performance of The Tempest I attended began with a sailor silently manning the helm, until a spectator shouted at him to "get on with it". ${ }^{12}$ In addition to

10 Though a full-fledged "hearsay" doctrine requiring that all quoted witnesses be brought to the stand would not take effect until the late seventeenth century, John H. Wigmore makes the point that "through the 1500s and down beyond the middle of the $1600 \mathrm{~s},[\ldots]$ the appreciation of the impropriety of using hearsay statements by persons not called is growing steadily" (Wigmore 444-45). The short-lived statute of 1553 even required the physical production of a witness in any trial for treason. Sir Walter Raleigh famously demanded that his accusers be produced in his 1603 trial, though his request was denied, due to supposedly overwhelming circumstantial evidence (443).

11 Lorna Hutson writes of "sixteenth-century developments in the participatory justice system involving the taking of written examinations by Justices, and the need for jurors to evaluate evidence at the bar [...]" (Hutson 6).

12 The production starred Vanessa Redgrave and was directed by Lenka Udovicki (London, The New Globe Theatre, 2000). 
frustration, the hand-rubbing, which stands in contrast to Lady Macbeth's previous murder-inciting words, may elicit pity. The gentlewoman's words "I would not have such a heart in my bosom, for the dignity of the whole body" (V.i.52-3) seem to call for such a response.

Issues of pity, empathy and catharsis are perhaps most powerfully evoked in the episode of Ross giving Macduff the news of his family's murder:

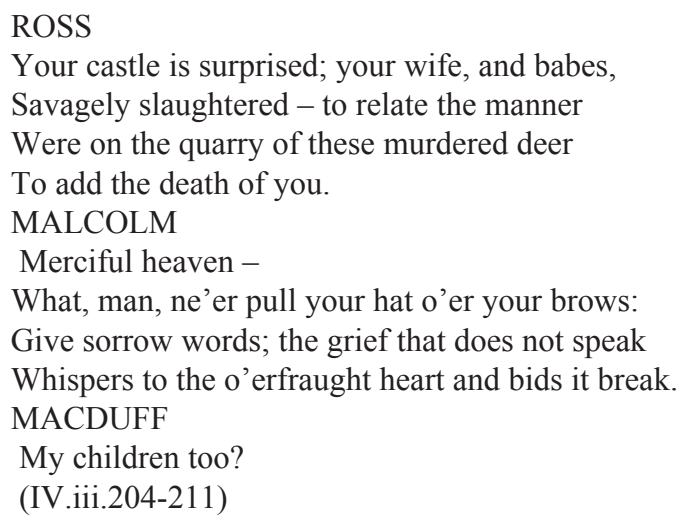

Words can kill, but they may also offer relief. Malcolm's advice to Macduff invokes the concept of purging, as is confirmed by his reference to "medicine" a few lines later. On the meta-dramatic level, this suggests the Aristotelian concept of catharsis, or purging of fear and pity through identification with a tragic character's situation. In a Shakespearian context, of course, one should be wary about speaking of catharsis, as Aristotle's Poetics, which introduced the term, were not printed in English until 1623, the same year Macbeth first appeared in print. And yet, Thomas Rist has convincingly argued that the concept of theatrical purgation was not alien to Shakespeare, as "Shakespeare explicitly explored the idea of theater as purgative in the Taming of the Shrew" (Rist 140). In the passage above, the issue of how to achieve purgation of negative emotions is raised. The paradox in Malcolm's instructions to Macduff is that telling the character not to pull his cap over his brows is an implicit stage-direction for the actor impersonating Macduff to do just that. This disconnect between the character's natural gesture and the actor's staged action suggests that achieving purgation on the individual level and catharsis on the theatrical level are two different things. Understanding why this should be so involves bringing in 
Galenic humoral theory, with its emphasis on the materiality of emotions, ${ }^{13}$ as well as print culture, with its emphasis on the materiality of words. ${ }^{14}$ Malcolm considers speech to be purgative through an implicit comparison with vomiting, both involving a physical expulsion of foulness from inside the body. This may work for the character, but not for the spectator who absorbs the words rather than expelling them. The actor's gesture, however, may work as a purgative for the audience, first because gestures are immediate, and mostly universal, ${ }^{15}$ but also because Macduff's pulling his cap over his brows is a theatrically effective way to suggest that he is weeping. In the writings of Shakespeare and his contemporaries, tears are both purgative and highly infectious, as when Prospero, in The Tempest, tells Gonzalo that his tears have caused him to shed "fellowly drops" (V.i.64), leading him to pity and forgive his enemies. In the Macduff scene, Shakespeare unfolds the process of empathetic response by exposing the audience to the full display of Macduff's sorrow, first the gesture, then the words, and finally his staged revenge.

\section{Conclusion}

In Macbeth, then, Shakespeare uses a pattern of objection to gestures to demonstrate the powerful dramatic effects of disconnecting word from gesture on the stage. In doing so, he is distancing his art from the classical rhetorical model. This does not mean, however, that he is distancing himself from the claim that drama promotes virtue, as empathy and purgation are presented as positive effects of performance and conducive to the health of the social body. Macbeth is replete with images of cleansing and purging, implicitly associating the benefits of spectacle with those of political action. ${ }^{16}$

13 This has been explored by Nancy Siraisi, Gail Kern Paster, Michael Schoenfeldt and others, based essentially on Robert Burton's Anatomy of Melancholy and Thomas Wright's Passions of the Mind in General. For Nancy Siraisi, "Humoural theory is probably the single most striking example of the habitual preference, in ancient, medieval, and Renaissance medicine, for materialist explanations of mental and emotional states" (106). Schoenfeldt discusses the prevalence of purging as a cure in Galenic medicine (3).

14 For a discussion of the impact of printing on the Renaissance perception of words, see Anderson.

15 Cicero emphasized the universal dimension of gesture in the third book of The Orator. " $[\mathrm{I}] \mathrm{t}$ is by action [...] that the illiterate, the vulgar, and even the barbarians themselves, are principally moved. For words move none but those who are associated in a participation in the same language; [...]; but action, which by its own powers displays the movements of the soul affects all mankind; for the minds of all men are excited by the same emotions which they recognize in others and indicate in themselves by the same token" (Cicero, Book 3, C. LX, 259).

16 These occur mainly in the third scene of the fifth act, first when Macbeth asks the physician whether he cannot "cleanse" his wife's "stuffed bosom" (V.iii.43), next when he asks him to "purge [his] land to a sound and pristine health" (V.iii.51) 
In a context of rising Puritanism on the one hand, and calls for a return to classicism on the other (in particular on the part of Ben Jonson), Shakespeare's Macbeth demonstrates the dramatic effectiveness of looser, more flexible ways of articulating speech and gesture. In this sense, Macbeth's treatment of gesture is part of the broader process of the commercial stage's emancipation from its roots in classical rhetoric and from the institutions that enshrined such origins in their practice, including grammar schools and the Inns of Court.

Macbeth's experimentation with speech and gesture anticipates later critical debates opposing mimetic and formalist theories of art. In particular, it anticipates T.S. Eliot's theory of the objective correlative. Eliot, reacting against Romantic views of art as the "spontaneous overflow of powerful feelings" ${ }^{17}$ (Wordsworth, §6), used Lady Macbeth's hand-wringing scene to illustrate his belief that emotion is conveyed by "a set of objects, a situation, a chain of events which shall be the formula of that particular emotion" (Eliot §7). Shakespeare's Macbeth, though still within the framework of the concept of art as imitation of both Nature and ancient authority, uses stage gestures to vigorously test the boundaries of that concept.

\section{Works Cited}

\section{Primary Sources}

BROME, Richard. The Antipodes. 1636. Ed. Ann Haaker. London: Edward Arnold Publishers, Ltd., 1967.

CICERO. On Oratory and Orators. Ed. J.S. Watson. New York: Harper and Brothers, 1875. URL: https://archive. org/stream/ciceroonoratorya00ciceuoft/ciceroonoratorya00ciceuoft_djvu.txt (accessed 30 October 2018).

DEKKER, Thomas. A Knights Conjuring, Done in Ernest, Discovered in Jest. London: Thomas Creede, 1607. Early English Books Online. Web. 30 October 2018. Huntington Library.

HEYWOOD, Thomas. A Defence of Drama. 1608. English Renaissance Literary Criticism. Ed. Brian Vickers. Oxford: Oxford University Press, 1999. 474-511.

JONSON, Ben. A Masque of Queenes. 1609. Reprinted from The Works of Benjamin Jonson. London: printed by William Stansby, 1616 (The first Folio). URL: http:/hollowaypages.com/jonson1692fame.htm (accessed 30 October 2018).

NASHE, Thomas. Summer's Last Will and Testament. Performed 1592; published 1600. Ed. J.B. Steane. The Unfortunate Traveller and Other Works. London: Penguin Classics, 1972.

17 The phrase is from Wordsworth's Preface to the Lyrical Ballads. 
QUINTILIAN. De Institutio Oratoria. Transl. H.E. Butler. Loeb Classical Library, Cambridge: Harvard University Press, 1920.

SHAKESPEARE, William. Hamlet. Ed. Harold Jenkins. Walton on Thames: Thomas Nelson \& Sons Ltd. (The Arden Shakespeare),1997; London: Methuen, 1982.

—. Macbeth. Ed. Nicholas Brooke. Oxford: Oxford University Press (World's Classics), 1998.

—. The Tempest. Ed. Stephen Orgel. Oxford: Oxford University Press, 2008.

WRIGHT, Thomas. The Passions of the Minde in Generall. London: Valentine Simmes and Adam Islip, 1604. Early English Books Online. Web. 30 October 2018.

\section{Secondary Sources}

ANDERSON, Judith. Words that Matter: Linguistic Perception in Renaissance English. Palo Alto: Stanford University Press, 1996.

ASTINGTON, John H. “Actors and the Body: Meta-theatrical rhetoric in Shakespeare”. Gesture 6:2 (2006): 241-259.

BARASCH, Frances K. "Shakespeare and the Puppet Sphere”. English Literary Renaissance 34:2 (Spring 2004): 157-175.

ELIOT, T.S. "Hamlet and his Problems". The Sacred Wood: Essays on Poetry and Criticism. New York: Alfred A. Knopf, 1921; Bartleby.com, 1996. URL: https://www.bartleby.com/200/ (accessed 30 October 2018).

HUTSON, Lorna. The Invention of Suspicion: Law and Mimesis in Shakespeare and Renaissance drama. 2007. Oxford: Oxford University Press, 2011.

KARIM-COOPER, Farah. The Hand on the Shakespearean Stage: Gesture, Touch and the Spectacle of Dismemberment. London: Bloomsbury Publishing, 2016.

KERN PASTER, Gail. Humouring the Body: Emotions and the Shakespearean Stage. Chicago: University of Chicago Press, 2010.

-. The Body Embarrassed: Drama and the Disciplines of Shame in Early Modern England. Ithaca: Cornell University Press, 1993.

LOPEZ, Jeremy. "Dumb Show”. Early Modern Theatricality. Ed. Henry S. Turner. Oxford: Oxford University Press, 2013. 291-305.

MEGARRY, Robert. A New Miscellany at Law: Yet Another Diversion for Lawyers and Others. London: Bloomsbury Publishing, 2005.

MEHL, Dieter. The Elizabethan Dumb Show. London: Methuen, 1965. 
MUKHERJI, Subha. Law and Representation in Early Modern England. Cambridge: Cambridge University Press, 2006.

RIST, Thomas. "Catharsis as Purgation in Shakespearean Drama”. Shakespearean Sensations: Experiencing Literature in Early Modern England. Eds. Katherine A. Craik and Tanya Pollard. Cambridge: Cambridge University Press, 2013. 138-156.

SCHOENFELDT, Michael C. Bodies and Selves in Early Modern England: Physiology and Inwardness in Spenser, Shakespeare, Herbert and Milton. Cambridge: Cambridge University Press, 1999.

SIRAISI, Nancy. Medieval and Early Renaissance Medicine: An Introduction to Knowledge and Practice. Chicago: University of Chicago Press, 1990.

WESLEY, John. “Original Gesture: Hand Eloquence on the Early Modern Stage”. Shakespeare Bulletin 35:1 (Spring 2017): 65-96.

WIGMORE, John. "The History of the Hearsay Rule”. Harvard Law Review 17:7 (May 1904): 437-458.

WILLS, Gary. Witches and Jesuits: Shakespeare's Macbeth. Oxford: Oxford University Press, 1995.

WORDSWORTH, William. The Lyrical Ballads (1800), Prefaces and Prologues. Vol. XXXIX. The Harvard Classics. New York: P.F. Collier \& Son, 1909-14; Bartleby.com, 2001. URL: https://www.bartleby. com/39/ (accessed 30 October 2018). 